\title{
Adsorption, Wetting, Growth, and Thermal Stability of the Protic Ionic Liquid Diethylmethylammonium Trifluoromethanesulfonate on $\mathrm{Ag}(111)$ and $\mathrm{Au}(111)$
}

Stephen Massicot, Tomoya Sasaki, Matthias Lexow, Sunghwan Shin, Florian Maier, Susumu Kuwabata, and Hans-Peter Steinrück*

Cite This: Langmuir 2021, 37, 11552-11560

Read Online

ABSTRACT: We have studied the adsorption, wetting, growth, and thermal evolution of the protic IL diethylmethylammonium trifluoromethanesulfonate ([dema][TfO] $)$ on $\mathrm{Au}(111)$ and $\mathrm{Ag}(111)$. Ultrathin films were deposited at room temperature (RT) and at $90 \mathrm{~K}$, and were characterized in situ by angle-resolved X-ray photoelectron spectroscopy. For both surfaces, we observe that independent of temperature, initially, a closed 2D wetting layer forms. While the film thickness does not increase past this wetting layer at RT, at $200 \mathrm{~K}$ and below, "moderate" $3 \mathrm{D}$ island growth occurs on top of the wetting layer. Upon heating, on
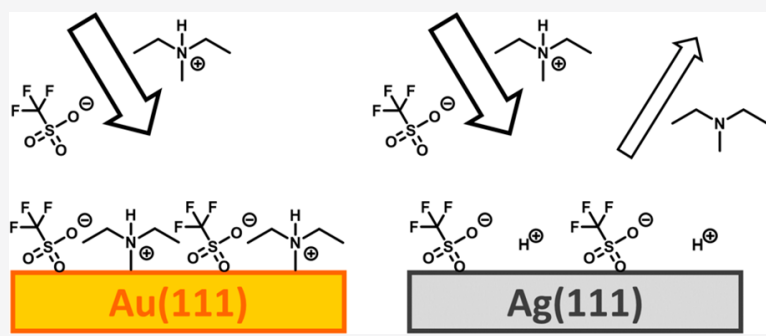
$\mathrm{Au}(111)$, the $[$ dema $][\mathrm{TfO}]$ multilayers desorb at $292 \mathrm{~K}$, leaving an intact [dema][TfO] wetting layer, which desorbs intact at $348 \mathrm{~K}$. The behavior on $\operatorname{Ag}(111)$ is much more complex. Upon heating [dema][TfO] deposited at $90 \mathrm{~K}$, the $[\text { dema }]^{+}$cations deprotonate in two steps at 185 and $305 \mathrm{~K}$, yielding $\mathrm{H}[\mathrm{TfO}]$ and volatile $[\text { dema }]^{0}$. At $355 \mathrm{~K}$, the formed $\mathrm{H}[\mathrm{TfO}]$ wetting layer partly desorbs $(\sim 50 \%)$ and partly decomposes to form an F-containing surface species, which is stable up to $570 \mathrm{~K}$.

\section{INTRODUCTION}

Ionic liquids (ILs) are salts that are composed of poorly coordinating ions and thus exhibit melting points typically well below $100{ }^{\circ} \mathrm{C}$. An interesting, but hitherto not much studied subset of ILs are protic ionic liquids (PILs), which are prepared through the stoichiometric neutralization of a strong Brønsted acid with a strong Brønsted base. ${ }^{1}$ This simple synthetic pathway makes them much cheaper than aprotic ionic liquids (AIL) and hence suitable for large-scale commercial applications. ${ }^{2,3}$ One further key feature, in contrast to AILs, is the proton availability for transfer reactions due to the presence of proton donor/proton acceptor sites. This property also allows for the formation of extensive hydrogen bond networks ${ }^{4}$ and makes PILs promising candidates as electrolytes in fuel cells and in catalysis. ${ }^{1-10}$ The PIL addressed in the present investigation, diethylmethylammonium trifluoromethanesulfonate, [dema][TfO] (Figure 1), e.g., enables reliable $\mathrm{O}_{2}$ reduction conditions due to its high and stable open-circuit potential combined with a wide liquid temperature range and high thermal stability. ${ }^{10}$

As fuel cells and catalysts usually are operated at elevated temperature, high thermal stability of the PIL at the interface of the electrode and catalyst material is of upmost interest. $^{5-7,9,10}$ In the present work, we characterize in detail the interface formed by [dema][TfO] with $\mathrm{Au}(111)$ and $\operatorname{Ag}(111)$ as model metal substrates. We investigated the temperature dependent stability of the PIL on both substrates.
On gold, the PIL remains intact; however, on silver, it deprotonates and partially decomposes. For future applications, these differences show the importance of choosing suitable PIL and electrode/catalyst material combinations.

Information on the adsorption, wetting, and growth of PILs on solid substrates also is highly relevant for applications like nanofabrication. On the basis of the very low vapor pressure of ILs in general, ${ }^{11,12}$ stable nanodroplets of PILs on solid supports have recently been used for templating nanostructures. $^{13,14}$ This is not possible with conventional molecular liquids due to their typically finite vapor pressure. ${ }^{14}$ Fundamental knowledge on the PIL/solid interaction and wetting characteristics is essential for understanding and tailoring the formation of such nanodroplets, and for rationalizing the sometimes unexpected interfacial properties of PILs. ${ }^{5}$ Other interesting applications are heterogeneous metal catalysis using PILs, ${ }^{15,16}$ batteries with PIL electrolyte, ${ }^{17,18}$ biomass processing with PILs, ${ }^{19,20}$ hydrogen storage

Received: July 8, 2021

Published: September 27, 2021 

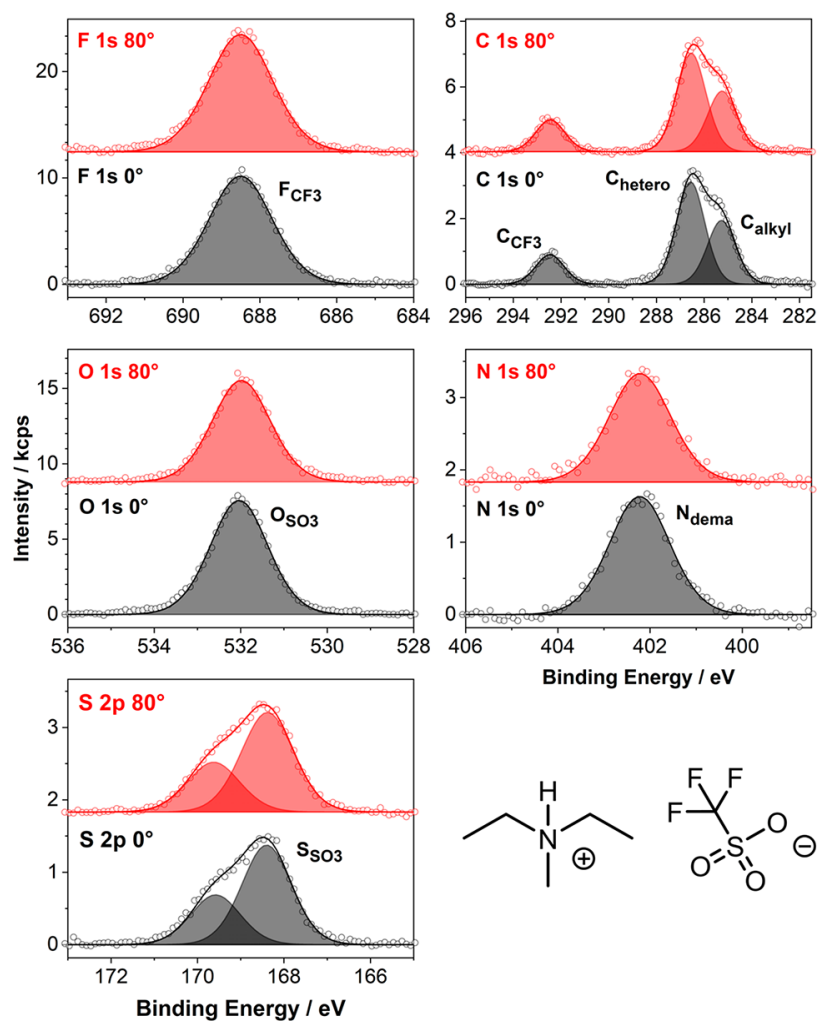

Figure 1. F 1s, C 1s, O 1s, N 1s, and $S$ 2p XP spectra of a macroscopic film of [dema][TfO] on a $\mathrm{Ag}$ foil at $\mathrm{RT}$, collected at $0^{\circ}$ (black) and $80^{\circ}$ (red) emission. At the right bottom, the molecular structure of diethylmethylammonium trifluoromethanesulfonate, $[$ dema $][\mathrm{TfO}]$, is shown.

in palladium in PIL electrolyte, ${ }^{21}$ and metal nanoparticle synthesis in PILs. ${ }^{22-27}$

The goal of this study thus is the detailed characterization of the PIL/support interface. Such information is presently not available. In the past, we already acquired extensive knowledge on interfacial characteristics of ultrathin AIL films on single crystal surfaces under well-defined ultrahigh vacuum (UHV) conditions (see, e.g., recent comprehensive review by Lexow et $\mathrm{al}^{28}$ ). This paper is to the best of our knowledge the first work addressing ultrathin PIL films under similar conditions.

We have chosen the above-mentioned PIL [dema][TfO] due to its melting point below RT $(260-267 \mathrm{~K}),{ }^{5,10}$ its high thermal stability (decomposition at $\sim 630 \mathrm{~K}$ ),,$^{5,10}$ and its equilibrium very far on the ionic side $\left(\Delta \mathrm{p} K_{\mathrm{a}}\right.$ well above $\left.17^{5,7,29}\right)$. Moreover, the electronic structure of macroscopic samples of [dema][TfO] has already been studied by X-ray photoelectron spectroscopy (XPS), ${ }^{30-32}$ proving the stability of this PIL under UHV and serving as references for our analysis.

We investigate ultrathin films of [dema][TfO] from submonolayer coverage up to several nanometer thickness, which are deposited by physical vapor deposition (PVD) on $\mathrm{Ag}(111)$ and $\mathrm{Au}(111)$ at temperatures between 90 and $300 \mathrm{~K}$; PVD allows for the preparation of ultraclean IL films of variable thickness under ultrahigh vacuum conditions. ${ }^{28,33}$ The experiments are performed by angle-resolved X-ray photoelectron spectroscopy (ARXPS). By measuring different electron emission angles of $0^{\circ}$ and $80^{\circ}$ with respect to the surface normal, we can tune our measurements from bulksensitive to surface-sensitive, respectively. Using $\mathrm{Al} \mathrm{K} \alpha$ radiation, the information depth (ID) at $0^{\circ}$ is $7-9 \mathrm{~nm}$, depending on the kinetic energy. At $80^{\circ}$, the ID is $1-1.5 \mathrm{~nm}$, which means that only the outermost surface layers are probed. For bulk ILs, ARXPS thus allows for extracting information on molecular orientation and enrichment effects at the IL/vacuum interface, and for ultrathin IL films, it provides access to the initial adsorption steps, molecular orientation, film growth, and decomposition effects. ${ }^{34}$ The two noble metal substrates $\mathrm{Ag}(111)$ and $\mathrm{Au}(111)$ were selected due to their overall low reactivity in general and with ultrathin AIL films in particular. For both, no reactions with metal atoms or reconstruction effects upon AIL deposition were found in previous studies. ${ }^{28,35}$ Nevertheless, $\mathrm{Ag}$ is known to be more reactive than $\mathrm{Au}$, e.g., it acts as heterogeneous catalyst for activating molecular oxygen in coupling reactions. ${ }^{36,37}$ By covering temperatures up to $600 \mathrm{~K}$, we also address the desorption of [dema][TfO] multilayers and wetting layers with a focus on adsorption strength, film stability, and thermal decomposition. ARXPS data collected from macroscopic [dema][TfO] samples are used as reference for our thin film studies. This work provides the beginning for $\mathrm{PIL} / \mathrm{metal}$ interface investigations on the molecular level and will serve as a basis for studies on more reactive PIL/support combinations.

\section{RESULTS AND DISCUSSION}

Macroscopic [dema][TfO] Film. We start with addressing a macroscopic [dema][TfO] film with around $0.1 \mathrm{~mm}$ thickness that was prepared ex situ by spreading the PIL on a polycrystalline $\mathrm{Ag}$ foil. At this film thickness, no influence of the substrate is expected. The corresponding ARXP spectra, taken at room temperature (RT), allow for verifying the purity of the PIL and serve as a reference system for comparison with the ultrathin films studied below.

Figure 1 shows $\mathrm{F} 1 \mathrm{~s}, \mathrm{C} 1 \mathrm{~s}, \mathrm{O} 1 \mathrm{~s}, \mathrm{~N} 1 \mathrm{~s}$, and $\mathrm{S} 2 \mathrm{p}$ spectra for emission angles of $0^{\circ}$ (normal emission, black) and $80^{\circ}$ (grazing emission, red) along with their fits (for details, see the Experimental Section). The $[\text { dema }]^{+}$cation displays two

Table 1. Film Composition as Determined from by XPS in Normal Emission $\left(0^{\circ}\right.$, top) and Grazing Emission $\left(80^{\circ} \text {, bottom }\right)^{a}$

\begin{tabular}{|c|c|c|c|c|c|c|c|}
\hline $0^{\circ}$ & $\mathrm{C}_{\mathrm{CF} 3}$ & $\mathrm{C}_{\text {hetero }}$ & $\mathrm{C}_{\text {alkyl }}$ & $\mathrm{N}_{\text {dema }}$ & $\mathrm{F}_{\mathrm{CF} 3}$ & $\mathrm{O}_{\mathrm{SO} 3}$ & $\mathrm{~S}_{\mathrm{SO} 3}$ \\
\hline atom number & $0.9 / 0.9(1)$ & $3.1 / 3.1(3)$ & $2.1 / 2.0(2)$ & $0.9 / 1.1(1)$ & $3.2 / 3.0(3)$ & $3.0 / 3.0(3)$ & $0.9 / 1.0(1)$ \\
\hline $\mathrm{BE} / \mathrm{eV}$ & $293.0 / 292.5$ & $286.9 / 286.6$ & 285.6/ 285.3 & $402.5 / 402.2$ & $689.1 / 688.5$ & $532.6 / 532.0$ & $168.9 / 168.4$ \\
\hline $80^{\circ}$ & $\mathrm{C}_{\mathrm{CF} 3}$ & $\mathrm{C}_{\text {hetero }}$ & $\mathrm{C}_{\text {alkyl }}$ & $\mathbf{N}_{\text {dema }}$ & $\mathbf{F}_{\mathrm{CF} 3}$ & $\mathrm{O}_{\mathrm{SO} 3}$ & $\mathrm{~S}_{\mathrm{SO} 3_{3}}$ \\
\hline atom number & $1.0 / 1.0(1)$ & $3.2 / 3.1(3)$ & $2.1 / 1.9(2)$ & $0.9 / 1.0(1)$ & $3.2 / 3.3(3)$ & $2.6 / 2.7(3)$ & $1.0 / 1.1(1)$ \\
\hline $\mathrm{BE} / \mathrm{eV}$ & $293.1 / 292.5$ & $287.0 / 286.5$ & $285.8 / 285.2$ & $402.6 / 402.2$ & $689.2 / 688.5$ & 532.8/ 532.0 & $169.1 / 168.4$ \\
\hline
\end{tabular}

${ }^{a}$ Also denoted are the corresponding binding energies. The bold values (left) corresponds to a $2.6 \mathrm{~nm}$ thick film of $[\mathrm{dema}][\mathrm{TfO}]$ on $\mathrm{Ag}(111)$ at 90 $\mathrm{K}$ prepared by $\mathrm{PVD}$, the italic values (right) to a macroscopic droplet of $\sim 0.1 \mathrm{~mm}$ thickness at RT; the nominal composition in atom numbers are given in (brackets). For $S 2 p$, the binding energy (BE) of the $S 2 p_{3 / 2}$ peak is given; the $S 2 \mathrm{p}_{1 / 2}$ peak is at $1.18 \mathrm{eV}$ higher $\mathrm{BE}$. 
distinct signals in the $\mathrm{C} 1 \mathrm{~s}$ and one in the $\mathrm{N} 1 \mathrm{~s}$ region. The $\mathrm{C}_{\text {hetero }}$ peak at $286.6 \mathrm{eV}$ binding energy $(\mathrm{BE})$ is assigned to the three carbon atoms in direct contact with the nitrogen (hetero) atom and the $\mathrm{C}_{\text {alkyl }}$ peak at $285.3 \mathrm{eV}$ is assigned to the two alkyl carbon atoms at the end of the ethyl groups. The $\mathrm{C}_{\text {alkyl }}: \mathrm{C}_{\text {hetero }}$ ratio of $3.1: 2.0$ at $0^{\circ}$ emission is in excellent agreement with the nominal ratio of $3: 2$. The single $\mathrm{N}_{\text {dema }}$ peak at $402.2 \mathrm{eV}$ corresponds to the ammonium nitrogen atom. $^{30-32}$ For the $[\mathrm{TfO}]^{-}$anion, we observe one peak each in the $\mathrm{C} 1 \mathrm{~s}, \mathrm{~F} 1 \mathrm{~s}$, and $\mathrm{O} 1 \mathrm{~s}$ region. The $\mathrm{C}_{\mathrm{CF} 3}$ peak at $292.5 \mathrm{eV}$ and the $\mathrm{F}_{\mathrm{CF} 3}$ peak at $688.5 \mathrm{eV}$ are assigned to carbon and fluorine atoms of the trifluoromethyl group, and the $\mathrm{O}_{\mathrm{SO} 3}$ peak at $532.0 \mathrm{eV}$ and the spin orbit-split $2 \mathrm{p}_{3 / 2} / 2 \mathrm{p}_{1 / 2} \mathrm{~S}_{\mathrm{SO} 3}$ doublet at $168.4 / 169.6 \mathrm{eV}$ are assigned to the oxygen and sulfur atoms of the sulfonate group. ${ }^{30-32}$

The quantitative analysis of the XP spectra of the macroscopic [dema][TfO] film is summarized in Table 1. For the bulk-sensitive spectra at $0^{\circ}$, the measured atom numbers obtained from the intensities of the different peaks (right value, italics) show excellent agreement with the nominal values (in brackets), within the accuracy of our measurements $( \pm 5 \%)$. For the $\sim 6 \times$ more surface-sensitive spectra at $80^{\circ}$, the $\mathrm{F} 1 \mathrm{~s}$ signal is higher than the nominal value ( 3.3 vs. 3.0 ), whereas the $\mathrm{O} 1 \mathrm{~s}$ signal is lower than the nominal value $(2.7$ vs 3.0$)$. We interpret this observation as an enrichment effect based on preferential orientation of the $[\mathrm{TfO}]^{-}$anion at the outer surface with the $\mathrm{CF}_{3}$ groups pointing toward the vacuum and the $\mathrm{SO}_{3}$ groups toward the bulk. ${ }^{13}$ A similar preferential enrichment at the $\mathrm{IL} /$ vacuum interface was reported also for AILs with $\mathrm{CF}_{3}$-containing anions such as bis[(trifluoromethyl)sulfonyl $]$ imide $^{13,38}$ and cations like 3-methyl-1-(3,3,4,4,4-pentafluorobutyl)imidazolium. $^{13,39,40}$

As will be demonstrated in the following sections, multilayer desorption, that is, evaporation of the [dema][TfO] film already starts around $290 \mathrm{~K}$, which indicates that macroscopic films are not fully stable at RT under UHV conditions. Notably, the evaporation temperature of this protic IL is lower than those of aprotic ILs (e.g., $345 \mathrm{~K}$ for $\left[\mathrm{C}_{1} \mathrm{C}_{1} \mathrm{Im}\right]\left[\mathrm{Tf}_{2} \mathrm{~N}\right]$ on $\operatorname{Ag}(111)$ - for an overview see Lexow et al. $\left.{ }^{28}\right)$, which we have studied in the past. Since the desorption rate of [dema][TfO] at RT is still very low, macroscopically thick films effectively provide a seemingly infinite reservoir on the time scale of film preparation and measurement. For ultrathin films of few multilayers thickness, however, the situation is quite different, as will be discussed below.

Growth of Ultrathin [dema][TfO] Films on Ag(111) and $A u(111)$. To study the adsorption and growth of [dema][TfO], increasing amounts of the PIL were deposited onto clean $\mathrm{Ag}(111)$ and $\mathrm{Au}(111)$ surfaces by PVD, with sample temperatures of $90 \mathrm{~K}, 200 \mathrm{~K}$ and RT. After each experiment, the crystal surfaces were cleaned by heating above $500 \mathrm{~K}$ (leading to thermal desorption), $\mathrm{Ar}^{+}$sputtering, and annealing.

In Table 1, we summarize the quantitative analysis of a 2.6 $\mathrm{nm}$ thick film of [dema][TfO] deposited and measured on $\mathrm{Ag}(111)$ at $90 \mathrm{~K}$; the corresponding spectra are shown in the SI, Figure S1. The composition values for this film as derived from the $0^{\circ}$ and $80^{\circ}$ ARXP spectra (left values in bold) show within the accuracy of our measurements $( \pm 10 \%$ for the ultrathin films, due to the low intensity of the IL signals and uncertainties in background subtraction) the same composition as that described above for the macroscopic film (italic numbers). This clearly indicates that $[$ dema $][$ TfO $]$ films can be prepared on $\operatorname{Ag}(111)$ by PVD in UHV without decomposition during evaporation and remain intact on the surface at low temperatures. The same holds true for [dema][TfO] films on $\mathrm{Au}(111)$ (see Figure S2 in the SI for a $2.4 \mathrm{~nm}$ film deposited at $200 \mathrm{~K}$ ).

The film growth behavior can be deduced from the attenuation of the substrate signal as a function of the amount of deposited IL, using our previously established approach (for details see refs. $^{28,33,35}$ ). For perfect $2 \mathrm{D}$ growth, the $\mathrm{Ag}$ or $\mathrm{Au}$ signals decrease exponentially from the value $I_{0}$ for the clean surface to the value $I_{d}$ for a $2 \mathrm{D}$ layer with thickness $d$, according to $I_{d} / I_{0}=\exp (-d /(\lambda \cdot \cos \vartheta))$, with $\vartheta$ being the electron emission angle relative to surface normal. For the inelastic mean free path $\lambda$ of $\mathrm{Ag} 3 \mathrm{~d}$ electrons (kinetic energy: $\sim 1100 \mathrm{eV}$ ), we employ $2.5 \mathrm{~nm},{ }^{35,41}$ for Au 4 f electrons (kinetic energy: $\sim 1400 \mathrm{eV}$ ), we use $3.0 \mathrm{~nm}^{42-45}$

In our analysis, we first determine the mean film thickness $d$ from the $I_{d} / I_{0}$ ratio at $0^{\circ}$ by assuming perfect $2 \mathrm{D}$ growth. In the next step, the $I_{d} / I_{0}$ ratio for this thickness at $80^{\circ}$ is calculated, and the experimentally measured ratio is then compared to this calculated value. Agreement between the two values indicates $2 \mathrm{D}$ growth, and an experimental $80^{\circ}$ value larger than the calculated one indicates a 3D morphology of the IL film. ${ }^{28}$ The height $h$ of a monolayer (1 ML) of $[$ dema $][\mathrm{TfO}]$ is estimated in agreement with previous publications: $:^{28,33}$ a closed film of $1 \mathrm{ML}$ coverage corresponds to a bilayer of cations and anions irrespective of their relative arrangement. On the basis of the molar volume of bulk [dema][TfO] $\left(183.6 \mathrm{~cm}^{3} / \mathrm{mol}\right),{ }^{46}$ a closed $1 \mathrm{ML}$ film has a height $h=0.67 \mathrm{~nm}$. On the other hand, a closed single layer of ions adsorbed next to each other, with $0.5 \mathrm{ML}$ coverage, has half of this height, that is, $0.34 \mathrm{~nm}$. Such a film is denoted as "wetting layer" (WL) in the following.

In Figure 2a, we plot the attenuation of the $\mathrm{Ag} 3 \mathrm{~d}$ signal at $0^{\circ}$ and $80^{\circ}$ emission as a function of the [dema][TfO] film thickness at $90 \mathrm{~K}$ (blue), $200 \mathrm{~K}$ (red), and RT (black). The solid and dashed lines indicate the behavior for perfect $2 \mathrm{D}$ growth at $0^{\circ}$ and $80^{\circ}$, respectively. Up to about $0.34 \mathrm{~nm}$ (or $0.5 \mathrm{ML}$ coverage), the $80^{\circ}$ data closely follows the prediction for $2 \mathrm{D}$ growth for all temperatures. This behavior indicates the formation of a closed wetting layer where the anions and cations adsorb next to each other alternatingly, that is, in a checkerboard-like structure with a saturation coverage of 0.5 ML. This adsorption behavior with both ions in direct contact with the metal surface was also observed for most AILs on metal surfaces so far. ${ }^{28}$

Interestingly, at RT, the film thickness does not increase past wetting layer coverage. This behavior is attributed to the onset of multilayer desorption already below RT as will be explained in the following section in more detail. At $200 \mathrm{~K}$ and below, the coverage continues to increase beyond the wetting layer coverage, but while it is still decreasing, the $80^{\circ}$ data points fall above the prediction for $2 \mathrm{D}$ growth. Such a behavior has been classified as "moderate" 3D island growth (that is, comparably flat 3D islands) on top of the initially formed wetting layer and is again quite commonly observed for ILs on various metal surfaces. $^{28}$

For the $\mathrm{Au}(111)$ surface, the film growth of $[$ dema $][\mathrm{TfO}]$ is very similar to that on $\operatorname{Ag}(111)$ as is evident from the attenuation of the $\mathrm{Au} 4 \mathrm{f}$ signal as a function of the film thickness in Figure 2b. Again, we do not observe multilayer growth at RT (black). At $200 \mathrm{~K}$ (red), first a closed wetting 


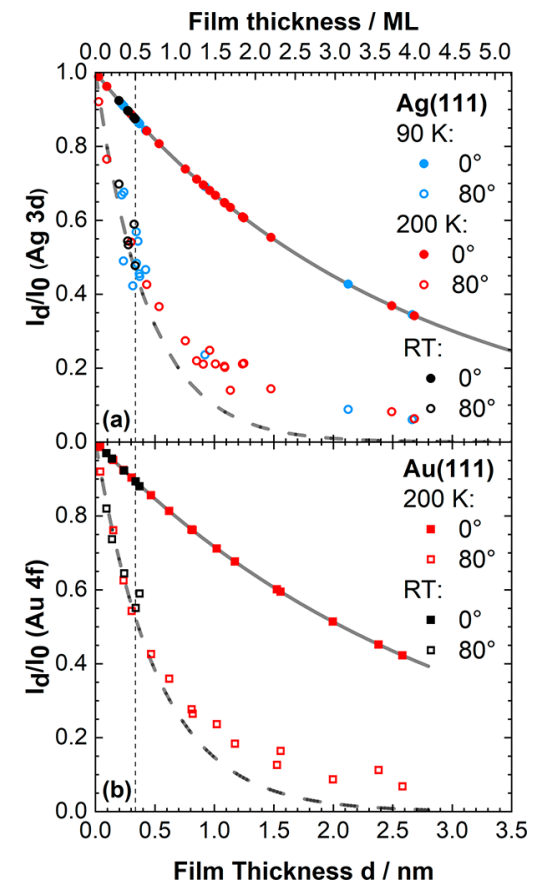

Figure 2. Dependence of the $\mathrm{Ag} 3 \mathrm{~d}$ (circles) and $\mathrm{Au} 4 \mathrm{f}$ (squares) substrate signals (intensity $I_{d}$ at film thickness $d$ divided by the intensity of the uncovered surface $\mathrm{I}_{0}$ ) upon deposition of [dema][TfO] on (a) $\mathrm{Ag}(111)$ and (b) $\mathrm{Au}(111)$, as a function of the film thickness (axis at bottom of the figure) and in units of monolayers (ML; axis at top of the figure). Data collected at $0^{\circ}$ are shown as closed symbols and data at $80^{\circ}$ as open symbols. The solid and dashed lines indicate the behavior for perfect $2 \mathrm{D}$ growth at $0^{\circ}$ and $80^{\circ}$, respectively. Measurements were performed at $90 \mathrm{~K}$ (blue), 200 $\mathrm{K}$ (red), and RT (black).

layer forms, followed by similarly moderate $3 \mathrm{D}$ growth as on $\operatorname{Ag}(111)$.

[dema][TfO] Wetting Layers on $\mathrm{Ag}(111)$ and $\mathrm{Au}(111)$. Next, we address the nature of the saturated wetting layers of [dema][TfO] on the two surfaces in detail. We start with discussing the results for $\mathrm{Au}(111)$, since the situation is more complex for $\operatorname{Ag}(111)$. In Figure $3 \mathrm{a}, \mathrm{C} 1 \mathrm{~s}, \mathrm{O} 1 \mathrm{~s}$, and $\mathrm{F} 1 \mathrm{~s}$ spectra at $0^{\circ}$ emission of $0.5 \mathrm{ML}$ on $\mathrm{Au}(111)$ deposited at RT are shown (note that all core level signals of the wetting layer
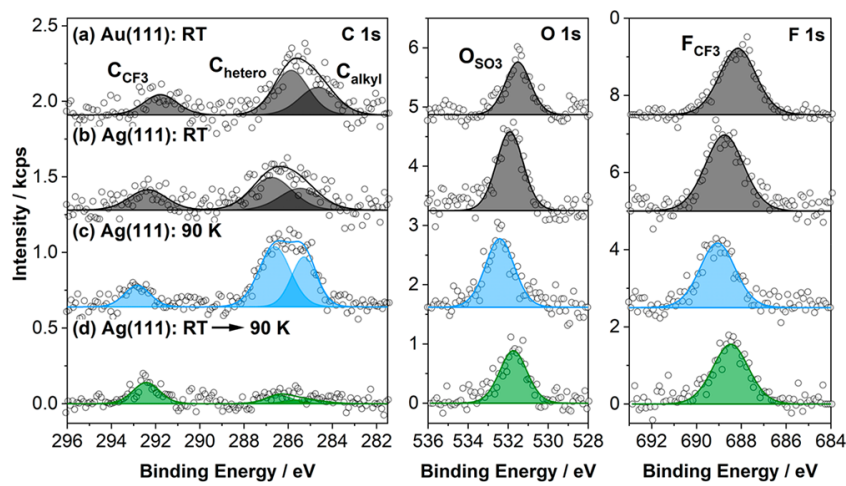

Figure 3. $\mathrm{C} 1 \mathrm{~s}, \mathrm{O} 1 \mathrm{~s}$, and $\mathrm{F} 1 \mathrm{~s}$ spectra at $0^{\circ}$ emission. (a) saturated wetting layer $(=0.5 \mathrm{ML})$ of $[\mathrm{dema}][\mathrm{TfO}]$ on $\mathrm{Au}(111)$ deposited at RT (black); (b) saturated wetting layer of [dema][TfO] on $\mathrm{Ag}(111)$ deposited at RT (black); (c) $0.5 \mathrm{ML}$ of [dema][TfO] on $\mathrm{Ag}(111)$ deposited at $90 \mathrm{~K}$ (blue); (d) after heating this film from $90 \mathrm{~K}$ to RT (green). are shifted by about $0.4-0.7 \mathrm{eV}$ toward lower binding energy with respect to the ones of the macroscopic films, which is attributed to improved final state screening by the metal in the photoemission process). ${ }^{43}$ The $S 2 \mathrm{p}$ and $\mathrm{N}$ 1s regions were not measured due to the low signal intensities for wetting layer coverages. The quantification of the signal intensities provides overall the nominal stoichiometry, albeit with slightly larger $\mathrm{CF}_{3}$-related $\mathrm{F} 1 \mathrm{~s}$ and $\mathrm{C}$ 1s signals and slightly lower cationic $\mathrm{C}$ $1 \mathrm{~s}$ and anionic $\mathrm{O}$ 1s signals (see Table 2). Quantification of the

Table 2. Composition of Layers as Obtained from Quantitative Analysis of Spectra Shown in Figure $3^{a}$

$\begin{array}{lccccc} & \mathrm{C}_{\mathrm{CF} 3} & \mathrm{C}_{\text {hetero }} & \mathrm{C}_{\text {alkyl }} & \mathrm{O}_{\mathrm{SO} 3} & \mathrm{~F}_{\mathrm{CF} 3} \\ \text { nominal } & \mathbf{1} & \mathbf{3} & \mathbf{2} & \mathbf{3} & \mathbf{3} \\ \text { (a) } \mathbf{A u}(111): \mathbf{R T} & 1.2 & 2.8 & 1.8 & 2.7 & 3.5 \\ \text { (b) } \operatorname{Ag}(111): \mathbf{R T} & 1.4 & 2.0 & 1.3 & 3.6 & 4.1 \\ \text { (c) } \operatorname{Ag}(111): 90 \mathrm{~K} & 0.9 & 3.0 & 2.0 & 3.1 & 3.0 \\ \text { (d) } \operatorname{Ag}(111): 90 \mathrm{~K} \rightarrow \mathbf{R T} & 1.7 & 0.7 & 0.4 & 4.2 & 5.1\end{array}$

a (a) Saturated wetting layer of [dema][TfO] on $\mathrm{Au}(111)$ deposited at RT (black); (b) saturated wetting layer layer of [dema][TfO] on $\mathrm{Ag}(111)$ deposited at RT (black); (c) $0.5 \mathrm{ML}$ of [dema][TfO] on $\mathrm{Ag}(111)$ deposited at $90 \mathrm{~K}$ (blue); (d) after heating this film from 90 $\mathrm{K}$ to RT (green).

XP spectra of the $\left[\right.$ dema] $\left[\right.$ TfO] wetting layer at $80^{\circ}$ emission (not shown) reveals an even stronger attenuation of the cationrelated contributions and the anion-related oxygen signal whereas anionic carbon and fluorine signals are relatively higher in intensity. This behavior indicates that the $[\mathrm{TfO}]^{-}$ anion adsorbs vertically on $\mathrm{Au}(111)$, with the $\mathrm{SO}_{3}$ group pointing toward and the $\mathrm{CF}_{3}$ group away from the metal surface. Similar preferential orientation of $[\mathrm{TfO}]^{-}$anion at $\mathrm{AIL} /$ metal interfaces was reported previously from in situ IR spectroscopy studies of 1-ethyl-3-methylimidazolium trifluoromethanesulfonate $\left(\left[\mathrm{C}_{2} \mathrm{C}_{1} \mathrm{Im}\right][\mathrm{TfO}]\right)$, on $\mathrm{Pd}(111)^{47-49}$ and on Co-covered $\operatorname{Pd}(111) .{ }^{50}$ For the $[\mathrm{dema}]^{+}$cation, our ARXPS results show no signs of preferential orientation.

The situation is different for the saturated layer of [dema][TfO] adsorbed on $\operatorname{Ag}(111)$ at RT as is evident from the corresponding C 1s, F 1s, and $\mathrm{O} 1 \mathrm{~s}$ spectra in Figure $3 \mathrm{~b}$. Notably, we observe a strong deviation from the expected stoichiometry: while the $\mathrm{C}_{\mathrm{CF} 3}, \mathrm{~F}_{\mathrm{CF} 3}$ and $\mathrm{O}_{\mathrm{SO} 3}$ signals of the anion are increased by about $30 \%$ compared to the nominal values, the cation-related $\mathrm{C}_{\text {hetero }}$ and $\mathrm{C}_{\text {alkyl }}$ signals are concomitantly decreased, which points to a considerable excess of $[\mathrm{TfO}]^{-}$in the wetting layer on $\operatorname{Ag}(111)$ at RT. Moreover, all absolute intensities of the anion signals are significantly higher $(35 \pm 8 \%)$ as compared to the saturated wetting layer on $\mathrm{Au}(111)$, which implies a larger amount of adsorbed anions on $\operatorname{Ag}(111)$ : taking F 1 s as the most intense anion signal for the saturated wetting layers at RT, we measure an absolute count rate of $3.4 \pm 0.4 \mathrm{kcps}$ for $\mathrm{Au}(111)$ versus 4.5 $\pm 0.5 \mathrm{kcps}$ for $\operatorname{Ag}(111)$. In addition to the observed intensity changes, we also find shifts of all peaks to higher binding energy, as compared to $\mathrm{Au}(111)$.

To understand the observed differences, we also measured $\mathrm{C}$ $1 \mathrm{~s}, \mathrm{~F} 1 \mathrm{~s}$, and $\mathrm{O} 1 \mathrm{~s}$ spectra at $0^{\circ}$ after depositing $0.5 \mathrm{ML}$ of [dema][TfO] on $\operatorname{Ag}(111)$ at $90 \mathrm{~K}$ (Figure 3c) and after subsequent heating to RT (Figure $3 \mathrm{~d}$ ). The $0^{\circ}$ spectra at $90 \mathrm{~K}$ match exactly the nominal composition indicating adsorption of intact [dema][TfO]. In particular, the observed $\mathrm{F}: \mathrm{O}=$ 2.9:3.1 ratio rules out pronounced anion orientation effects at 
this low temperature, where a hit-and-stick adsorption behavior has been observed for AILs. ${ }^{39,41}$ After heating to $\mathrm{RT}$, the anion-related $\mathrm{C} 1 \mathrm{~s}, \mathrm{~F} 1 \mathrm{~s}$, and $\mathrm{O} 1 \mathrm{~s}$ peaks shift by about $-0.5 \mathrm{eV}$ to lower binding energy. More importantly, the cationic C $1 \mathrm{~s}$ signals drastically decrease in intensity.

Since desorption of isolated cations is not possible due to energetic reasons (note that thermal evaporation of ILs only takes place in form of neutral ion pairs ${ }^{51}$ ), the substantial loss in cation XPS signals clearly points toward decomposition of the $[\text { dema }]^{+}$cations in the wetting layer on $\operatorname{Ag}(111)$. As the changes in XP spectra occur during heating to RT (see also next section), we propose that the $\mathrm{Ag}(111)$ surface, in contrast to $\mathrm{Au}(111)$, enables deprotonation of the ammonium cation to form neutral diethylmethylamine $\left([\mathrm{dema}]^{0}\right)$, with the latter desorbing from the surface, which leaves $\mathrm{H}^{+}$and $[\mathrm{TfO}]^{-}$as adsorbed trifluoromethanesulfonic acid, $\mathrm{H}[\mathrm{TfO}]$, behind. The observed shifts of the anion signals to lower binding energy upon heating thus might indeed be related to this cation exchange process. The remaining $[\mathrm{TfO}]^{-}$anions are welloriented at RT with the oxygen atoms pointing toward the $\mathrm{Ag}$ surface and the $\mathrm{CF}_{3}$ groups toward vacuum as shown by the $\mathrm{F}$ : $\mathrm{O}=5.1: 4.2=1.2$ ratio (this ratio is similar to that of the [dema][TfO] wetting layer on $\mathrm{Au}(111)$ at RT; see Table 2).

With this reaction in mind, our findings for the saturated wetting layer deposited on $\mathrm{Ag}(111)$ at $\mathrm{RT}$ in Figure 3b can be explained. In course of the deposition of [dema][TfO] at RT, part of the $[\text { dema }]^{+}$cations deprotonate and leave the surface as neutral diethylmethylamine. The liberated space allows for further [dema][TfO] adsorption next to $\mathrm{H}[\mathrm{TfO}]$ sites, which explains the overall higher amount of $[\mathrm{TfO}]^{-}$anions mentioned above. Since we still observe notable C 1s contributions related to intact $[\mathrm{dema}]^{+}$cations in Figure $3 \mathrm{~b}$, the deprotonation process described above apparently leads not to a full layer of $\mathrm{H}[\mathrm{TfO}]$ but rather to a wetting layer consisting of [dema][TfO] and $\mathrm{H}[\mathrm{TfO}]$ adsorbed next to each other. This also explains why the binding energies of the $F 1$ s and $\mathrm{O} 1 \mathrm{~s}$ peaks of the RT-deposited film in Figure $3 \mathrm{~b}$ lie between the values for the $0.5 \mathrm{ML}$ film at $90 \mathrm{~K}$ (Figure 3c) and the values obtained after subsequently heating this film to RT (Figure 3d).

Thermal Evolution of [dema][TfO] on $\mathrm{Au}(111)$ and $\mathrm{Ag}$ (111). To investigate the desorption of [dema] [TfO] from $\mathrm{Au}(111)$, we heated a $1.5 \mathrm{ML}$ film from 196 to $401 \mathrm{~K}$ at a heating rate of $2 \mathrm{~K} / \mathrm{min}$ and simultaneously recorded $\mathrm{Au} 4 \mathrm{f}$ spectra of the substrate and $\mathrm{F} 1 \mathrm{~s}$ spectra representative of the [TfO $]^{-}$anion all at $0^{\circ}$ emission (see Figure S3 in the SI). The quantitative analysis of the data is shown in Figure $4 \mathrm{a}$. The intensity of anion-related F 1s signal (red) decreases in two well-separated steps while the $\mathrm{Au} 4 \mathrm{f}$ intensity (gray) of the $\mathrm{Au}(111)$ crystal increases accordingly. With reference to previous desorption studies of ILs on $\mathrm{Ag}(111)$ and $\mathrm{Au}(111),{ }^{28,35,39,41}$ we interpret the first step with an inflection point of $292 \pm 2 \mathrm{~K}$ as multilayer desorption of [dema][TfO]. From a simple leading edge-type analysis, ${ }^{28,52}$ we obtain an activation energy of multilayer desorption of $E_{\mathrm{a}}=101 \pm 10 \mathrm{~kJ} /$ mol. This value agrees within the margins of error with the value of $91 \pm 15 \mathrm{~kJ} / \mathrm{mol}$ reported by Hessey et al. ${ }^{53}$ with an preexponential factor of $10^{16} \mathrm{~s}^{-1}$, and also with an earlier report of the enthalpy of vaporization of a structurally very similar IL, [triethylammonium][TfO], of $104.9 \pm 1.3 \mathrm{~kJ} / \mathrm{mol} .^{51}$ The onset of multilayer desorption below RT provides the explanation for the absence of multilayer growth at RT described above. The remaining intensity of $3.4 \pm 0.4 \mathrm{kcps}$

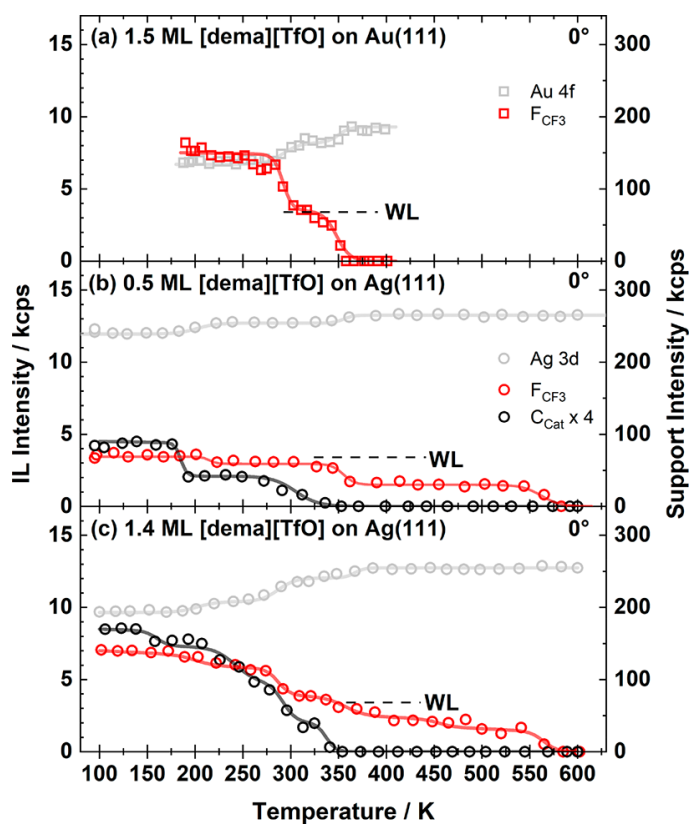

Figure 4. Thermal evolution of $\mathrm{F}$ 1s (red), C 1s (black), Au 4f (gray), and $\mathrm{Ag} 3 \mathrm{~d}$ (gray) signal intensities at $0^{\circ}$ emission upon heating films of [dema][TfO] deposited at low temperature. (a) 1.5 ML on $\mathrm{Au}(111)$, (b) $0.5 \mathrm{ML}$ on $\mathrm{Ag}(111)$, and (c) $1.4 \mathrm{ML}$ on $\mathrm{Ag}(111)$. Heating rate: $2 \mathrm{~K} / \mathrm{min}$. The dashed lines indicate the nominal intensity of a saturated wetting layer $(\mathrm{WL})$ of [dema][TfO] as determined from XPS after direct deposition on $\mathrm{Au}(111)$ at RT and on $\mathrm{Ag}(111)$ at $90 \mathrm{~K}$. The solid lines serve as guide to the eye.

between 300 and $340 \mathrm{~K}$ is ascribed to the wetting layer in direct contact with the $\mathrm{Au}(111)$ substrate and indicates its higher stability compared to the multilayers. The second desorption step at $348 \pm 2 \mathrm{~K}$ is attributed to the desorption of the $[$ dema] [TfO] wetting layer from the $\mathrm{Au}(111)$ surface. XPS after heating above $400 \mathrm{~K}$ shows no IL residuals in the F 1s, C $1 \mathrm{~s}$ and $\mathrm{O} 1 \mathrm{~s}$ region on $\mathrm{Au}(111)$. Hence we conclude that [dema][TfO] desorbs intact from $\mathrm{Au}(111)$.

After discussing the behavior on $\mathrm{Au}(111)$, we address the significantly more complex thermal evolution of [dema][TfO] from $\operatorname{Ag}(111)$ for two different initial coverages, 0.5 and 1.4 ML. The behavior of the F 1 s and $C 1$ s signals for $0.5 \mathrm{ML}$ is shown in Figure $4 \mathrm{~b}$. This coverage corresponds to a wetting layer completely covering the surface. The anion-related F 1s intensity (red symbols) is initially constant and shows a slight decrease from $\sim 3.4$ to $\sim 2.9 \mathrm{kcps}$ at $\sim 215 \mathrm{~K}$. Thereafter, it stays constant up to $\sim 355 \mathrm{~K}$ where it decreases by $\sim 50 \%$ to $\sim 1.5$ kcps, stays constant, and finally vanishes at $\sim 570 \mathrm{~K}$; these intensity changes are also reflected by changes of the $F$ is binding energy from $688.9 \pm 0.1 \mathrm{eV}(<200 \mathrm{~K})$ to $688.5 \pm 0.3$ $\mathrm{eV}$ and finally to $687.9 \pm 0.2 \mathrm{eV}(>350 \mathrm{~K})$; see Figure S4 in the SI. The cation-related C 1s signal (black) shows a quite different behavior, that is, it decreases to zero in two steps with inflection points at $185 \pm 2 \mathrm{~K}$ and $305 \pm 2 \mathrm{~K}$. This behavior is interpreted as follows. At $185 \mathrm{~K}$, roughly half of the [dema $]^{+}$ cations deprotonate yielding $\mathrm{H}[\mathrm{TfO}]$, with the neutral diethylmethylamine desorbing, which leads to the decrease of the $\mathrm{C} 1 \mathrm{~s}$ signal. The minor step in the $\mathrm{F} 1 \mathrm{~s}$ signals at $215 \mathrm{~K}$ could be a temperature-induced reorientation of the [TfO $]^{-}$ anion. At $305 \mathrm{~K}$, the remaining $[\mathrm{dema}]^{+}$cations deprotonate yielding $\mathrm{H}[\mathrm{TfO}]$ and diethylmethylamine desorption. At 355 $\mathrm{K}$, the formed $\mathrm{H}[\mathrm{TfO}]$ wetting layer partly desorbs ( $50 \%)$, 
which leads to the decrease of the F 1s signals, and partly decomposes to form a F-containing decomposition product, which is stable up to $570 \mathrm{~K}$. Alternatively, $50 \%$ of $\mathrm{H}$ [TfO] could be stable up $570 \mathrm{~K}$, which however appears unlikely to us. Each desorption step is accompanied by a slight increase in the $\mathrm{Ag} 3 \mathrm{~d}$ substrate signal, due to less damping by the adsorbed species. Notably, the $\mathrm{H}[\mathrm{TfO}]$ desorption temperature of $355 \mathrm{~K}$ on $\mathrm{Ag}(111)$ is very similar to that of the [dema][TfO] wetting layer on $\mathrm{Au}(111)$.

The corresponding behavior of the 1.4 ML film is shown in Figure $4 \mathrm{c}$ and in Figure S5 in the SI. This coverage corresponds to a full wetting layer plus multilayers (equivalent of $\sim 2$ wetting layers) on top of it. The anion-related F 1s signal is constant at $6.8 \pm 0.4 \mathrm{kcps}$ up to $190 \mathrm{~K}$, and thereafter slightly decreasing to $5.8 \pm 0.4 \mathrm{kcps}$, which is accompanied by a slight increase of the $\mathrm{Ag} 3 \mathrm{~d}$ signal. This behavior could be again due to reorganization orientation of the anions. At $\sim 287$ $\mathrm{K}$ and $\sim 350 \mathrm{~K}$ (inflection points), the $\mathrm{F} 1 \mathrm{~s}$ signals show small step-like decreases, which are followed by continuous decease, until the signal disappears at $570 \mathrm{~K}$. The cation-related $\mathrm{C} 1 \mathrm{~s}$ signal again evolves independently from the anion signals. It stay more or less constant up to $215 \mathrm{~K}$, apart from a slight decrease at $\sim 150 \mathrm{~K}$, which could be due to reorientation effects. Above $215 \mathrm{~K}$, the $\mathrm{C}$ 1s signal decreases continuously to zero until $350 \mathrm{~K}$. The behavior observed for $1.4 \mathrm{ML}$ can be understood along the lines discussed for the $0.5 \mathrm{ML}$ film. Starting at $\sim 215 \mathrm{~K}$, a fraction of the $[\text { dema }]^{+}$cations deprotonate yielding $\mathrm{H}[\mathrm{TfO}]$ and a decrease of the $\mathrm{C} 1 \mathrm{~s}$ signal due to diethylmethylamine desorption. This process continues up to $350 \mathrm{~K}$, where the $\mathrm{C} 1 \mathrm{~s}$ signal disappears. The step-like decrease of the $\mathrm{F} 1 \mathrm{~s}$ signal and the simultaneous decrease of the $\mathrm{C} 1 \mathrm{c}$ signals at $287 \mathrm{~K}$ is attributed to a desorption of remaining [dema][TfO] multilayers, from the similarity of this temperature to the multilayer desorption temperature on $\mathrm{Au}(111)$. The small step-like decrease of the $\mathrm{F}$ 1 s signals at $\sim 350 \mathrm{~K}$, where for $0.5 \mathrm{ML}$ a pronounced step was seen, is attributed to the onset of the decomposition of $\mathrm{H}[\mathrm{TfO}]$ to a F-containing surface species, which is stable up to $570 \mathrm{~K}$.

\section{CONCLUSIONS}

The goal of this study is the detailed characterization of the adsorption, wetting, growth, and thermal evolution of protic IL [dema][TfO] films deposited onto the noble metal $\mathrm{Au}(111)$ and $\operatorname{Ag}(111)$ surfaces under well-defined UHV conditions. The quantitative analysis of several $\mathrm{nm}$ thick films showed the same behavior as that observed for a macroscopically thick film, which was studied as reference, confirming that [dema][TfO] remains intact upon evaporation. From angleresolved XPS measurements, we deduce a preferential orientation of the $[\mathrm{TfO}]^{-}$anions at the $\mathrm{IL} /$ vacuum interface with the $\mathrm{CF}_{3}$ group preferentially pointing toward the vacuum side and the $\mathrm{SO}_{3}$ groups pointing toward the bulk, in line with previous observations for aprotic ILs.

The ultrathin films of [dema][TfO] were deposited on $\mathrm{Ag}(111)$ and $\mathrm{Au}(111)$ at 90, 200, and $300 \mathrm{~K}$ and characterized in situ by ARXPS. We studied the growth behavior via the attenuation of the $\mathrm{Ag} 3 \mathrm{~d}$ and $\mathrm{Au} 4 \mathrm{f}$ signals at electron emission angles of $0^{\circ}$ and $80^{\circ}$. Overall, we observe a similar behavior for both surfaces. For all studied temperatures, we observe the initial growth of a closed 2D wetting layer. At RT, the film thickness does not increase past this wetting layer coverage due to multilayer desorption starting at around $290 \mathrm{~K}$. Below 200
$\mathrm{K}$, the coverage continues to increase, with "moderate" $3 \mathrm{D}$ island growth on top of the initially formed wetting layer.

$\mathrm{On} \mathrm{Au}(111)$, [dema][TfO] is stable at RT. In contrast, on the more reactive $\operatorname{Ag}(111)$ surface, the $[\text { dema }]^{+}$cations partly deprotonate well below RT yielding $\mathrm{H}[\mathrm{TfO}]$ and neutral diethylmethylamine $[\mathrm{dema}]^{0}$. The formed amine is volatile and desorbs instantaneously leaving a mixture of $\mathrm{H}[\mathrm{TfO}]$ and [dema][TfO] on the surface. Consequently, a higher coverage of $[\mathrm{TfO}]^{-}$is achieved than on $\mathrm{Au}(111)$ due to the smaller size of $\mathrm{H}^{+}$as compared to [dema $]^{+}$. When adsorbing a WL of [dema][TfO] on $\operatorname{Ag}(111)$ at $90 \mathrm{~K}$ and subsequently heating to $\mathrm{RT}$, nearly all [dema][TfO] is deprotonated to $\mathrm{H}[\mathrm{TfO}]$. The larger amount of intact [dema][TfO] observed for adsorption at RT in comparison to the amount obtained after adsorption at $90 \mathrm{~K}$ plus heating to RT is attributed to further adsorption of intact $[$ dema $][\mathrm{TfO}]$ at free adsorption sites after desorption of $[\text { dema }]^{0}$.

Further insight was obtained by following the thermal evolution in situ during heating, after deposition at low temperature. On $\mathrm{Au}(111)$, we deposited 1.5 ML [dema][TfO] at $200 \mathrm{~K}$ and subsequently heated it to $400 \mathrm{~K}$. We observe the desorption of the [dema][TfO] multilayer at $292 \mathrm{~K}$, leaving an intact [dema][TfO] wetting layer on $\mathrm{Au}(111)$. The onset of multilayer desorption below RT is the reason for the absence of multilayer growth at RT. The wetting layer desorbs intact at $348 \mathrm{~K}$ leaving a clean $\mathrm{Au}(111)$ surface above $400 \mathrm{~K}$.

The behavior on $\operatorname{Ag}(111)$ is much more complex. Upon heating a [dema][TfO] wetting layer $(0.5 \mathrm{ML})$ deposited at 90 $\mathrm{K}$, we observe that the $[\text { dema }]^{+}$cations deprotonate in two steps at 185 and $305 \mathrm{~K}$, yielding $\mathrm{H}[\mathrm{TfO}]$ and volatile [dema $]^{0}$. At $355 \mathrm{~K}$, the formed $\mathrm{H}[\mathrm{TfO}]$ wetting layer partly desorbs $(\sim 50 \%)$ and partly decomposes forming a F-containing surface species, which is stable up to $570 \mathrm{~K}$. The behavior observed for a $1.4 \mathrm{ML}$ [dema][TfO] film deposited at $90 \mathrm{~K}$ and heated up to $600 \mathrm{~K}$ can be understood along the deprotonation effects at the Ag-PIL interface as found in the wetting layer film superimposed by the multilayer signals.

All in all, our results demonstrate a rather complex behavior of this protic IL in contact with the moderately reactive $\mathrm{Ag}(111)$ surface even well below room temperature. The discussed deprotonation effects should thus be taken into consideration in all situations where PIL/solid interfaces are present such as in electrochemistry, nanoparticle formation, and many more, particularly, when more reactive metals than silver are involved.

\section{EXPERIMENTAL SECTION}

The synthesis and characterization of [dema][TfO] was described in ref 54. After careful degassing in UHV, it was deposited onto $\mathrm{Au}(111)$ and $\operatorname{Ag}(111)$ via physical vapor deposition (PVD) in UHV from a modified Knudsen cell with a boron nitride crucible at a temperature between 343 and $353 \mathrm{~K}$, which provides a very stable IL flux; the details of the Knudsen cell have been published in ref 41. The PIL flux was monitored with a quartz crystal microbalance before and after deposition to ensure a constant evaporation rate. We found no signs of decomposition of [dema][TfO] in our quantitative XPS analysis of multilayer films from PVD on $\mathrm{Ag}(111)$ at $90 \mathrm{~K}$ and $\mathrm{Au}(111)$ at $200 \mathrm{~K}$. This behavior is in line with literature reports, where decomposition of bulk [dema][TfO] is only found at temperatures above $633 \mathrm{~K}^{10}$ Furthermore, it agrees also with more recent observations for a similar PIL, [triethylammonium][TfO], which has been shown to evaporate as ion pairs. ${ }^{51,55}$

The $\operatorname{Ag}(111)$ and $\mathrm{Au}(111)$ single crystals with circular shapes were purchased from MaTeck (15 mm in diameter, purity $99.999 \%$, 
polished with an alignment better than $0.1^{\circ}$ to the (111) plane). They were cleaned in UHV by short heating to $>500 \mathrm{~K}$ and subsequent $\mathrm{Ar}^{+}$ sputtering $(600 \mathrm{~V}, 8 \mu \mathrm{A})$ for $30 \mathrm{~min}$ at $\mathrm{RT}$, followed by an annealing step at $800 \mathrm{~K}$ for $10 \mathrm{~min}$. The surface temperature was measured using type- $\mathrm{K}$ thermocouple wires inserted into a $0.5 \mathrm{~mm}$ pinhole of the crystal with an absolute accuracy of $\pm 20 \mathrm{~K}$ (at $500 \mathrm{~K}$ ) and a reproducibility of $\pm 2 \mathrm{~K}$.

The UHV system for angle-resolved X-ray photoelectron spectroscopy (ARXPS) contains a nonmonochromated $\mathrm{Al} \mathrm{K} \alpha$ X-ray source (SPECS XR 50, $1486.6 \mathrm{eV}, 240 \mathrm{~W}$ ) and a hemispherical electron analyzer (VG SCIENTA R3000) (described in more detail in ref 35). A pass energy of $100 \mathrm{eV}$ was applied for all spectra leading to an overall energy resolution of about $0.9 \mathrm{eV}^{35}$ The spectra were quantitatively evaluated in CasaXPS V2.3.16Dev6. Shirley backgrounds ${ }^{56}$ were subtracted for $\mathrm{Ag} 3 \mathrm{~d}$ and $\mathrm{Au} 4 \mathrm{f}$ core levels. For the $\mathrm{F}$ $1 \mathrm{~s}, \mathrm{C} 1 \mathrm{~s}, \mathrm{O} 1 \mathrm{~s}, \mathrm{~S} 2 \mathrm{p}$, and $\mathrm{N}$ 1s regions, linear backgrounds were subtracted and then peaks were fitted with Voigt profiles (30\% Lorentzian contribution). The binding energy scale for XPS of the macroscopic films of [dema][TfO] was calibrated such that the $\mathrm{F}_{\mathrm{CF} 3}$ peak is located at $688.5 \mathrm{eV}^{30-32}$ The spectra of thin films of the ILs of $\mathrm{Ag}(111)$ and $\mathrm{Au}(111)$ were referenced to the Fermi edge yielding $368.20 \mathrm{eV}$ for the $\mathrm{Ag} 3 \mathrm{~d}_{5 / 2}$ level and $83.85 \mathrm{eV}$ for the $\mathrm{Au} 4 \mathrm{f}_{7 / 2}$ level. In agreement with literature, ${ }^{31,32}$ we fitted the $\mathrm{C} 1$ s components related to the $[\mathrm{dema}]^{+}$cation with two contributions: $\mathrm{C}_{\text {hetero }}$ for the three carbon atoms directly bonded to the nitrogen atom and $\mathrm{C}_{\text {alkyl }}$ for the two alkyl carbon atoms further away from the central nitrogen atom. For the measurements of the wetting layer in $0^{\circ}$ emission, we applied a constraint to the peak areas of $C_{\text {hetero }} / C_{\text {alkyl }}=3: 2$. Additionally, we subtracted a residual carbon contamination signal that could not be removed even after repeated cleaning cycles from both surfaces. In case of $\mathrm{Ag}(111)$, we also subtracted the $\mathrm{K}_{\beta}$ satellite of the $\mathrm{Ag} 3 \mathrm{~d}$ signal above $296 \mathrm{eV}$. Temperature-programmed XPS was measured at a heating rate of $2 \mathrm{~K} / \mathrm{min}$.

\section{ASSOCIATED CONTENT}

\section{(s) Supporting Information}

The Supporting Information is available free of charge at https://pubs.acs.org/doi/10.1021/acs.langmuir.1c01823.

Additional XPS spectra addressing the chemical composition and thermal evolution of ultrathin [dema][TfO] films (PDF)

\section{AUTHOR INFORMATION}

\section{Corresponding Author}

Hans-Peter Steinrück - Lehrstuhl für Physikalische Chemie 2, Friedrich-Alexander-Universität Erlangen-Nürnberg, 91058 Erlangen, Germany; 이이.org/0000-0003-1347-8962; Email: hans-peter.steinrueck@fau.de

\section{Authors}

Stephen Massicot - Lehrstuhl für Physikalische Chemie 2, Friedrich-Alexander-Universität Erlangen-Nürnberg, 91058 Erlangen, Germany; 이이.org/0000-0002-2530-8015

Tomoya Sasaki - Department of Applied Chemistry, Graduate School of Engineering, Osaka University, Suita, Osaka 565-0871, Japan; 이이.org/0000-0001-55035823

Matthias Lexow - Lehrstuhl für Physikalische Chemie 2, Friedrich-Alexander-Universität Erlangen-Nürnberg, 91058 Erlangen, Germany; (i) orcid.org/0000-0002-1441-2909

Sunghwan Shin - Lehrstuhl für Physikalische Chemie 2, Friedrich-Alexander-Universität Erlangen-Nürnberg, 91058 Erlangen, Germany

Florian Maier - Lehrstuhl für Physikalische Chemie 2, Friedrich-Alexander-Universität Erlangen-Nürnberg, 91058 Erlangen, Germany; 이이.org/0000-0001-9725-8961
Susumu Kuwabata - Department of Applied Chemistry, Graduate School of Engineering, Osaka University, Suita, Osaka 565-0871, Japan; 이이.org/0000-0002-4606964X

Complete contact information is available at: https://pubs.acs.org/10.1021/acs.langmuir.1c01823

\section{Notes}

The authors declare no competing financial interest.

\section{ACKNOWLEDGMENTS}

H.-P.S. and M.L. thank the European Research Council (ERC) for support through the Advanced Investigator Grant "ILID" to H.-P.S. (grant agreement no. 693398-ILID) under the European Union's Horizon 2020 research and innovation programme. S. S. thanks the Alexander von Humboldt Foundation for a research fellowship. S.M. was funded by the Deutsche Forschungsgemeinschaft (DFG, German Research Foundation) - Project-ID 431791331 - SFB 1452.

\section{REFERENCES}

(1) Greaves, T. L.; Drummond, C. J. Protic Ionic Liquids: Properties and Applications. Chem. Rev. 2008, 108, 206-237.

(2) Brzeczek-Szafran, A.; Wiecławik, J.; Barteczko, N.; Szelwicka, A.; Byrne, E.; Kolanowska, A.; Swadźba Kwaśny, M.; Chrobok, A. Protic Ionic Liquids from Di- or Triamines: Even Cheaper Brønsted Acidic Catalysts. Green Chem. 2021, 23, 4421-4429.

(3) Chen, L.; Sharifzadeh, M.; Mac Dowell, N.; Welton, T.; Shah, N.; Hallett, J. P. Inexpensive Ionic Liquids: $\left[\mathrm{HSO}_{4}\right]$-Based Solvent Production at Bulk Scale. Green Chem. 2014, 16, 3098-3106.

(4) Greaves, T. L.; Drummond, C. J. Protic Ionic Liquids: Evolving Structure-Property Relationships and Expanding Applications. Chem. Rev. 2015, 115, 11379-11448.

(5) Lee, S.-Y.; Ogawa, A.; Kanno, M.; Nakamoto, H.; Yasuda, T.; Watanabe, M. Nonhumidified Intermediate Temperature Fuel Cells Using Protic Ionic Liquids. J. Am. Chem. Soc. 2010, 132, 9764-9773.

(6) Pourcelly, G. Membranes for Low and Medium Temperature Fuel Cells. State-of-the-Art and New Trends. Pet. Chem. 2011, 51, 480-491.

(7) Yoshizawa, M.; Xu, W.; Angell, C. A. Ionic Liquids by Proton Transfer: Vapor Pressure, Conductivity, and the Relevance of $\Delta$ pka from Aqueous Solutions. J. Am. Chem. Soc. 2003, 125, 15411-15419.

(8) Hallett, J. P.; Welton, T. Room-Temperature Ionic Liquids: Solvents for Synthesis and Catalysis. 2. Chem. Rev. 2011, 111, 35083576.

(9) Yasuda, T.; Watanabe, M. Protic Ionic Liquids: Fuel Cell Applications. MRS Bull. 2013, 38, 560-566.

(10) Nakamoto, H.; Watanabe, M. Brønsted Acid-Base Ionic Liquids for Fuel Cell Electrolytes. Chem. Commun. 2007, 2539-2541.

(11) Lovelock, K. R. J. Quantifying Intermolecular Interactions of Ionic Liquids Using Cohesive Energy Densities. R. Soc. Open Sci. 2017, 4, 171223.

(12) Esperanca, J. M. S. S.; Canongia Lopes, J. N.; Tariq, M.; Santos, L. M. N. B. F.; Magee, J. W.; Rebelo, L. P. N. Volatility of Aprotic Ionic Liquids - a Review. J. Chem. Eng. Data 2010, 55, 3-12.

(13) Lovelock, K. R. J. Influence of the Ionic Liquid/Gas Surface on Ionic Liquid Chemistry. Phys. Chem. Chem. Phys. 2012, 14, 50715089.

(14) Yu, H.; Dyett, B. P.; Pathirannahalage, S. K.; Li, M.; Drummond, C. J.; Greaves, T. L. Formation of Surface Protic Ionic Liquid Nanodroplets for Nanofabrication. Adv. Mater. Interfaces 2020, 7, 1901647.

(15) Johnson, L.; Ejigu, A.; Licence, P.; Walsh, D. A. Hydrogen Oxidation and Oxygen Reduction at Platinum in Protic Ionic Liquids. J. Phys. Chem. C 2012, 116, 18048-18056. 
(16) Ejigu, A.; Johnson, L.; Licence, P.; Walsh, D. A. Electrocatalytic Oxidation of Methanol and Carbon Monoxide at Platinum in Protic Ionic Liquids. Electrochem. Commun. 2012, 23, 122-124.

(17) Ingale, P.; Sakthivel, M.; Drillet, J. F. Test of Diethylmethylammonium Trifluoromethanesulfonate Ionic Liquid as Electrolyte in Electrically Rechargeable Zn/Air Battery. J. Electrochem. Soc. 2017, 164, H5224-H5229.

(18) Meng, T.; Young, K.-H.; Wong, D. F.; Nei, J. Ionic LiquidBased Non-Aqueous Electrolytes for Nickel/Metal Hydride Batteries. Batteries 2017, 3, 4.

(19) George, A.; et al. Design of Low-Cost Ionic Liquids for Lignocellulosic Biomass Pretreatment. Green Chem. 2015, 17, 17281734.

(20) Verdía, P.; Brandt, A.; Hallett, J. P.; Ray, M. J.; Welton, T. Fractionation of Lignocellulosic Biomass with the Ionic Liquid 1Butylimidazolium Hydrogen Sulfate. Green Chem. 2014, 16, 16171627.

(21) Pająk, M.; Hubkowska, K.; Czerwiński, A. The Study of Hydrogen Sorption in Palladium Limited Volume Electrode from Dema-Tfo Ionic Liquid. J. Electroanal. Chem. 2018, 825, 73-76.

(22) Hamm, S. C.; et al. Sputter-Deposition of Silver Nanoparticles into Ionic Liquid as a Sacrificial Reservoir in Antimicrobial Organosilicate Nanocomposite Coatings. ACS Appl. Mater. Interfaces 2012, 4, 178-184.

(23) Bhujbal, A. V.; Raut, A. B.; Bhanage, B. M. Water-Assisted Electrochemical Fabrication of $\mathrm{Cu} / \mathrm{Cu}_{2} \mathrm{O}$ Nanoparticles in Protic Ionic Liquid and Their Catalytic Activity in the Synthesis of Quinazolinones. React. Kinet., Mech. Catal. 2020, 131, 905.

(24) Izumi, R.; Yao, Y.; Tsuda, T.; Torimoto, T.; Kuwabata, S. PtNanoparticle-Supported Carbon Electrocatalysts Functionalized with a Protic Ionic Liquid and Organic Salt. Adv. Mater. Interfaces 2018, 5, 1701123.

(25) Sasaki, T.; Uematsu, T.; Tsuda, T.; Kuwabata, S. Operando Observation of Vacuum and Liquid Interface While Conducting Gold Sputtering onto Ionic Liquid for Preparation of Au Nanoparticles. Electrochemistry 2018, 86, 223-225.

(26) Tsuda, T.; Kurihara, T.; Hoshino, Y.; Kiyama, T.; Okazaki, K.i.; Torimoto, T.; Kuwabata, S. Electrocatalytic Activity of Platinum Nanoparticles Synthesized by Room-Temperature Ionic LiquidSputtering Method. Electrochemistry 2009, 77, 693-695.

(27) Yoshii, K.; Tsuda, T.; Arimura, T.; Imanishi, A.; Torimoto, T.; Kuwabata, S. Platinum Nanoparticle Immobilization onto Carbon Nanotubes Using Pt-Sputtered Room-Temperature Ionic Liquid. RSC Adv. 2012, 2, 8262-8264.

(28) Lexow, M.; Maier, F.; Steinrück, H.-P. Ultrathin Ionic Liquid Films on Metal Surfaces: Adsorption, Growth, Stability and Exchange Phenomena. Advances in Physics: X 2020, 5, 1761266.

(29) Miran, M. S.; Kinoshita, H.; Yasuda, T.; Susan, M. A. B. H.; Watanabe, M. Physicochemical Properties Determined by $\Delta$ pka for Protic Ionic Liquids Based on an Organic Super-Strong Base with Various Brønsted Acids. Phys. Chem. Chem. Phys. 2012, 14, 51785186.

(30) Fogarty, R. M.; Matthews, R. P.; Ashworth, C. R.; BrandtTalbot, A.; Palgrave, R. G.; Bourne, R. A.; Hoogerstraete, T. V.; Hunt, P. A.; Lovelock, K. R. J. Experimental Validation of Calculated Atomic Charges in Ionic Liquids. J. Chem. Phys. 2018, 148, 193817.

(31) Fogarty, R. M.; Palgrave, R. G.; Bourne, R. A.; Handrup, K.; Villar-Garcia, I. J.; Payne, D. J.; Hunt, P. A.; Lovelock, K. R. J. Electron Spectroscopy of Ionic Liquids: Experimental Identification of Atomic Orbital Contributions to Valence Electronic Structure. Phys. Chem. Chem. Phys. 2019, 21, 18893-18910.

(32) Fogarty, R. M.; Rowe, R.; Matthews, R. P.; Clough, M. T.; Ashworth, C. R.; Brandt, A.; Corbett, P. J.; Palgrave, R. G.; Smith, E. F.; Bourne, R. A.; Chamberlain, T. W.; Thompson, P. B. J.; Hunt, P. A.; Lovelock, K. R. J.; et al. Atomic Charges of Sulfur in Ionic Liquids: Experiments and Calculations. Faraday Discuss. 2018, 206, 183-201. (33) Cremer, T.; Killian, M.; Gottfried, J. M.; Paape, N.; Wasserscheid, P.; Maier, F.; Steinrück, H.-P. Physical Vapor Deposition of [Emim][Tf2n]: A New Approach to the Modification of Surface Properties with Ultrathin Ionic Liquid Films. ChemPhysChem 2008, 9, 2185-2190.

(34) Steinrück, H.-P. Recent Developments in the Study of Ionic Liquid Interfaces Using X-Ray Photoelectron Spectroscopy and Potential Future Directions. Phys. Chem. Chem. Phys. 2012, 14, $5010-5029$.

(35) Lexow, M.; Talwar, T.; Heller, B. S. J.; May, B.; Bhuin, R. G.; Maier, F.; Steinrück, H.-P. Time-Dependent Changes in the Growth of Ultrathin Ionic Liquid Films on $\mathrm{Ag}(111)$. Phys. Chem. Chem. Phys. 2018, 20, 12929-12938.

(36) Wittstock, A.; et al. Nanoporous Au: An Unsupported Pure Gold Catalyst? J. Phys. Chem. C 2009, 113, 5593-5600.

(37) Xu, B.; Siler, C.; Madix, R.; Friend, C., Ag/Au Mixed Sites Promote Oxidative Coupling of Methanol on the Alloy Surface. Chem. - Eur. J. 2014, 20.4646

(38) Maier, F.; Cremer, T.; Kolbeck, C.; Lovelock, K. R. J.; Paape, N.; Schulz, P. S.; Wasserscheid, P.; Steinrück, H. P. Insights into the Surface Composition and Enrichment Effects of Ionic Liquids and Ionic Liquid Mixtures. Phys. Chem. Chem. Phys. 2010, 12, 1905-1915.

(39) Lexow, M.; Heller, B. S. J.; Partl, G.; Bhuin, R. G.; Maier, F.; Steinrück, H.-P. Cation Exchange at the Interfaces of Ultrathin Films of Fluorous Ionic Liquids on $\mathrm{Ag}(111)$. Langmuir 2019, 35, 398-405.

(40) Heller, B.; Lexow, M.; Greco, F.; Shin, S.; Partl, G. J.; Maier, F.; Steinrück, H.-P., Temperature-Dependent Surface Enrichment Effects in Binary Mixtures of Fluorinated and Non-Fluorinated Ionic Liquids. Chem. - Eur. J. 2020, 26.1117

(41) Lexow, M.; Heller, B. S. J.; Maier, F.; Steinrück, H.-P. Anion Exchange at the Liquid/Solid Interface of Ultrathin Ionic Liquid Films on $\mathrm{Ag}(111)$. ChemPhysChem 2018, 19, 2978-2984.

(42) Rietzler, F.; May, B.; Steinrück, H. P.; Maier, F. Switching Adsorption and Growth Behavior of Ultrathin [C2C1Im] [Otf] Films on $\mathrm{Au}(111)$ by Pd Deposition. Phys. Chem. Chem. Phys. 2016, 18, 25143-25150.

(43) Cremer, T.; Stark, M.; Deyko, A.; Steinrück, H. P.; Maier, F. Liquid/Solid Interface of Ultrathin Ionic Liquid Films: [C1C1Im]$[\mathrm{Tf} 2 \mathrm{~N}]$ and $[\mathrm{C} 8 \mathrm{C} 1 \mathrm{Im}][\mathrm{Tf} 2 \mathrm{~N}]$ on $\mathrm{Au}(111)$. Langmuir 2011, 27, 3662-3671.

(44) Deyko, A.; Bajus, S.; Rietzler, F.; Bösmann, A.; Wasserscheid, P.; Steinrück, H.-P.; Maier, F. Interface Properties and Physicochemical Characterization of the Low-Temperature Molten Salt Li/K/Cs Acetate. J. Phys. Chem. C 2013, 117, 22939-22946.

(45) Rietzler, F.; Piermaier, M.; Deyko, A.; Steinrück, H.-P.; Maier, F. Electrospray Ionization Deposition of Ultrathin Ionic Liquid Films: $[\mathrm{C} 8 \mathrm{C} 1 \mathrm{Im}] \mathrm{Cl}$ and $[\mathrm{C} 8 \mathrm{C} 1 \mathrm{Im}][\mathrm{Tf} 2 \mathrm{~N}]$ on $\mathrm{Au}(111)$. Langmuir 2014, 30, $1063-1071$.

(46) Atilhan, M.; Anaya, B.; Ullah, R.; Costa, L. T.; Aparicio, S. Double Salt Ionic Liquids Based on Ammonium Cations and Their Application for Co2 Capture. J. Phys. Chem. C 2016, 120, 1782917844 .

(47) Bauer, T.; Mehl, S.; Brummel, O.; Pohako-Esko, K.; Wasserscheid, P.; Libuda, J. Ligand Effects at Ionic Liquid-Modified Interfaces: Coadsorption of $[\mathrm{C} 2 \mathrm{C} 1 \mathrm{Im}][\mathrm{Otf}]$ and $\mathrm{Co}$ on $\mathrm{Pd}(111) . J$. Phys. Chem. C 2016, 120, 4453-4465.

(48) Schernich, S.; Kostyshyn, D.; Wagner, V.; Taccardi, N.; Laurin, M.; Wasserscheid, P.; Libuda, J. Interactions between the RoomTemperature Ionic Liquid $[\mathrm{C} 2 \mathrm{C} 1 \mathrm{Im}][\mathrm{Otf}]$ and $\mathrm{Pd}(111)$, WellOrdered Al2o3, and Supported Pd Model Catalysts from Ir Spectroscopy. J. Phys. Chem. C 2014, 118, 3188-3193.

(49) Schernich, S.; Wagner, V.; Taccardi, N.; Wasserscheid, P.; Laurin, M.; Libuda, J. Interface Controls Spontaneous Crystallization in Thin Films of the Ionic Liquid [C2C1Im][Otf] on Atomically Clean Pd(111). Langmuir 2014, 30, 6846-6851.

(50) Mehl, S.; Bauer, T.; Brummel, O.; Pohako-Esko, K.; Schulz, P.; Wasserscheid, P.; Libuda, J. Ionic-Liquid-Modified Hybrid Materials Prepared by Physical Vapor Codeposition: Cobalt and Cobalt Oxide Nanoparticles in [C1C2Im][Otf] Monitored by in Situ Ir Spectroscopy. Langmuir 2016, 32, 8613-8622.

(51) Zaitsau, D. H.; Emel'yanenko, V. N.; Stange, P.; Verevkin, S. P.; Ludwig, R. Dissecting the Vaporization Enthalpies of Ionic Liquids by 
Exclusively Experimental Methods: Coulomb Interaction, Hydrogen Bonding, and Dispersion Forces. Angew. Chem., Int. Ed. 2019, 58, $8589-8592$.

(52) Lexow, M.; Massicot, S.; Maier, F.; Steinrück, H.-P. Stability and Exchange Processes in Ionic Liquid/Porphyrin Composite Films on Metal Surfaces. J. Phys. Chem. C 2019, 123, 29708-29721.

(53) Hessey, S.; Jones, R. On the Evaporation, Bonding, and Adsorbate Capture of an Ionic Liquid on $\mathrm{Au}(111)$. Chem. Sci. 2013, 4, $2519-2529$.

(54) Sasaki, T.; Inoue, S.; Kuwabata, S. Room-Temperature Fabrication of Electrocatalyst for Oxygen Reduction Using $\mathrm{Pt}$ Nanoparticle-Dispersed Protic Ionic Liquid with Poly(3,4-Ethylenedioxythiophene). Electrochemistry 2021, 89, 83-86.

(55) Horikawa, M.; Akai, N.; Kawai, A.; Shibuya, K. Vaporization of Protic Ionic Liquids Studied by Matrix-Isolation Fourier Transform Infrared Spectroscopy. J. Phys. Chem. A 2014, 118, 3280-3287.

(56) Shirley, D. A. High-Resolution X-Ray Photoemission Spectrum of the Valence Bands of Gold. Phys. Rev. B 1972, 5, 4709-4714. 